doi: 10.52370/TISC2129JA

\title{
COVID CRISIS AND TOURISM EVOLUTION IN SOME EUROPEAN COUNTRIES: ADAPT TO REALITIES OR REINVENT THE FUTURE?
}

\author{
Jean Vasile Andrei ${ }^{1}$; Mihaela Cristina Drăgoi ${ }^{2}$
}

\begin{abstract}
The health crisis has exerted a significant pressure on the global economic system, implicitly on the evolution of tourism, value chain creation and supply chains, generating shocks on various national economic sectors. In this context, the objective of the paper is to make a brief synoptic analysis on the evolution of the tourism sector in some EU countries. Two periods of time were considered - before the onset of the pandemic (2018-2019) and during the pandemic (in 2020). The results of the analysis confirm the specific trends of reducing the multiplicative effects that tourism has on the economy as well as the decrease, even contracting of the sector, a phenomenon identified through specific analyzed indicators.
\end{abstract}

Key Words: crisis, COVID-19, travel, transformation, resilience, tourism JEL classification: $F 63, O 11, Z 3$

\section{Introduction}

In the conditions of evolution and adaptation of the global economy to the new demands imposed by the manifestation of the health crisis, tourism represents one of the most affected economic sectors, whose return and recovery mechanisms will be subject to a relatively long process of adaptation to new economic realities. At the same time, as found in Zhang et al. (2021), for many regions and states, tourism has become a strategic industry in the functional and highly competitive market economy, being one of the strategic pillars in ensuring the well-being of communities and

\footnotetext{
1 Jean Vasile Andrei, Ph.D., full prof., Petroleum-Gas University of Ploiesti, B-dul Bucuresti, No. 39, Ploiesti, Prahova, Romania, andrei_jeanvasile@yahoo.com

2 Mihaela Cristina Drăgoi, Ph.D., full prof., Faculty of International Business and Economics, The Bucharest University of Economic Studies, 6 Romană Square, 010374 Bucharest, Romania, cristina.dragoi@rei.ase.ro
} 
economic growth, given its significant contribution to the formation of Gross Domestic Product (GDP). This factual reality that for some countries tourism is already a determining factor in ensuring economic well-being, mobilizing important labor, financial and investment resources, being also a source of income for a significant category of population, requires more than ever, the understanding of the realities specific to the field, constituting equally an important step in deepening these aspects.

The tourism industry has known and experienced negative episodes with significant sectoral effects, until the manifestation of the COVID-19 crisis, the field being affected by an important series of "black swan" crisis events. Social unrest, volcanic eruptions, travel restrictions, airline strikes, the financial crises of 1997 and 2008, the SARS epidemic of 2003 and now the health crisis generated by COVID-19 are just some of the stages of the "black swan" crisis that marked the evolution of this industry. The declaration of the COVID-19 crisis as a pandemic on March 11, 2020 by the World Health Organization imposed on the tourism sector a new reality to which it must adapt, reform and reinvent in order to survive. As argued by Strielkowski (2020), the coronavirus pandemic and the current health crisis will profoundly affect the tourism and travel sector and will impose new approaches in the practice of tourism throughout the value chain, from travelers to travel agencies, hotels and air companies. Lapointe (2020) discusses the need to reconnect tourism with the development needs of local communities which dependend on tourism as a core activity, against the background of promoting a survival strategy, in which the elements of health safety and security are cumulatively integrated, further highlighting the possibility of a reinforcement of the alterity and delinking of tourism in a "6 foot-tourism world". On the other hand, some authors (Chang et al., 2020) propose the development and application of a charter for tourism, travel and hospitality industry after the COVID-19 period as a contribution to substantiating the general framework of this activity and diversifying ways of practicing tourism. Rifkin (2019) also proposes a Green New Deal that is compatible with the new pandemic reality, respectively a rethinking and resettlement of the pardigm on tourism in which the global community spirit resiliently imposes a new ethic of competitiveness. However, any type of measures eventually adopted requires an understanding of the new reality from a fundamentally changed perspective in terms of tourism and tourism activities. Mass tourism, practiced so far, will bear drastic limitations in most tourist destinations, precisely to comply with health restrictions. 
In the context of the paradigm shifts imposed by the COVID-19 crisis, the tourism industry must identify resilient solutions for a wide range of problems and challenges, starting with those of territorial cohesion, those of a social nature and ending with those of sectoral perspective, culture or traditions. Equally, the health crisis emphasizes the need to strengthen responses to the impact of climate change and adaptation to structural changes generated by tourism, in the process of reorientation to the new economic and social paradigm.

Tourism and activities related to this sector play a fundamental role in the European economy as a whole, being, as contended by the European Commission (2007a), one of the economic activities with the most significant potential for growth and development mobilization in many states and regions. The indirect contribution of tourism to other economic activities generates an intrinsic set of effects, developing numerous synergies in close interaction between the main beneficiaries, without excluding the environment, society and new technologies (Andrei et al., 2014; Andrei \& Drăgoi, 2020; Ciolac et al., 2017). As acknowledged by the European Commission (2007b), the tourism sector is of major importance in creating new jobs in the economy as well as in diversifying the supply of jobs for young people, which are twice as numerous in this sector as in the rest of the economy. When analyzing adventure travel and tourism in the post-crisis health conditions, Nepal (2020) claims that COVID-19 offered the adventure tourism industry a major opportunity to reset and rethink previously used strategies, becoming a sustainable tool in promoting sustainability and responsible capitalization of existing potentials. As highlighted by Higgins-Desbiolles (2021), in the current economic conditions, the COVID-19 pandemic began to impose a new paradigm in the field of tourism, becoming both a large-scale challenge or, even more, a game-changer for travel and tourism in general.

Tourism and the ecosystem generated around this economic branch represent for many contemporary economies a potentiating factor of economic growth, not only by capitalizing on the available natural potential, but also by the multiplier effect that this branch has on the economy in general. From this perspective, the effects of the health crisis are much more complex, difficult to measure and highlight and with a duration that is closely determined by the health measures adopted in the field. The new health reality emphasized and tested the degree of flexibility of contemporary economies in adapting to extraordinary situations and in strengthening the level of resilience of national economy systems in 
mitigating socioeconomic consequences to allow resumption of economic activity and sectoral recovery. The socio-economic consequences generated by the COVID-19 pandemic, as several authors claim (Fotiadis et al., 2021; Villacé-Molinero et al., 2021), will be long-lasting and felt unequally in different European states, requiring extensive sectoral support measures and considerable budgetary allocation.

As recognized by Lew et al. (2020), the COVID-19 pandemic has globally caused a collapse next to dilution of the human-earth system, requiring a significant reorganization of this system by reconsidering the acceptance of innovation and creativity as part of the new economic and social reality in the process of adapting to the new demands. Tourism, as an exclusively dependent activity based on the exploitation of the human-earth system and on geographical resources, must therefore adapt to the new context of the planet in order to be able to function further. Tourism, unlike other contemporary economic activities, develops an entire ecosystem of interdependent activities, which generates financial and resource flows, involving multiplier synergies, as described in Figure 1.

Figure 1: Tourism ecosystem approach

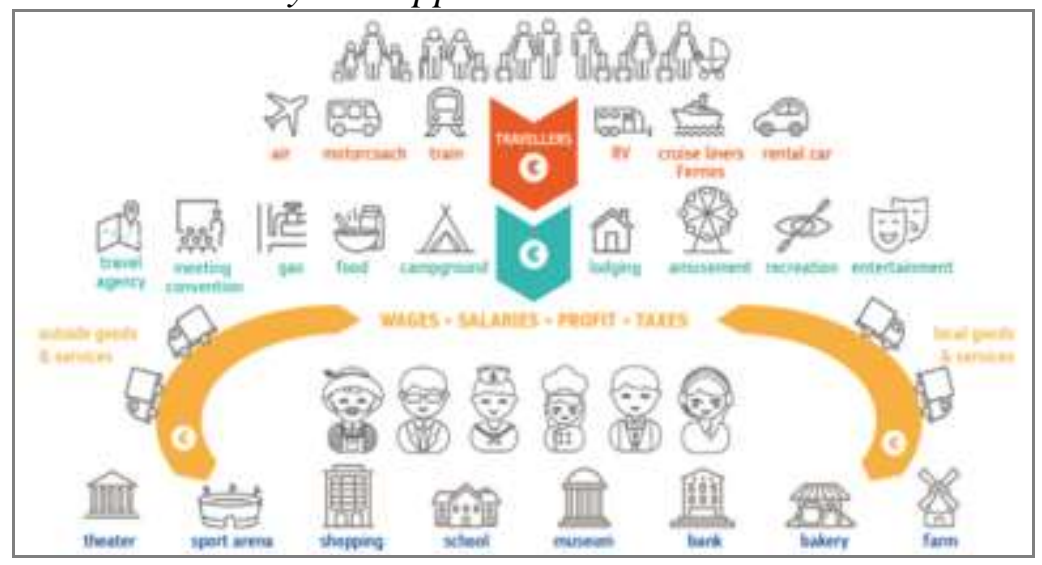

Source: Authors' caption from the European Commission, (2020), Tourism and transport in 2020 and beyond, (05 March 2021)

Tourism and the tourism industry, through the deterministic links and interrelationships between resources and highly diverse mobilized factors, has a particularly important role in the development of contemporary society, often positively or negatively correlated with economic growth, regional or local communities' development as well as with the need for resilient development of the global economy. Figure 1 allows observing the 
interdependencies determined by tourism in all contemporary economies. The multiplication effect held on the global economic system imposes tourism, not only from the perspective of a leisure activity, but also as a factor of economic growth and mobilization of the capitalization of the available economic potentials. The tourism generated connections create synergies, sometimes difficult to understand, but which highlight more and more its potentiating factor on economic growth. However, the COVID-19 crisis exposed the vulnerabilities of the regions in which tourism was the main economic activity. In this sense, Figure 2 shows the Regional vulnerability map in the EU based on the Vulnerability index.

Figure 2: Regional vulnerability map in EU based on Vulnerability index ${ }^{3}$

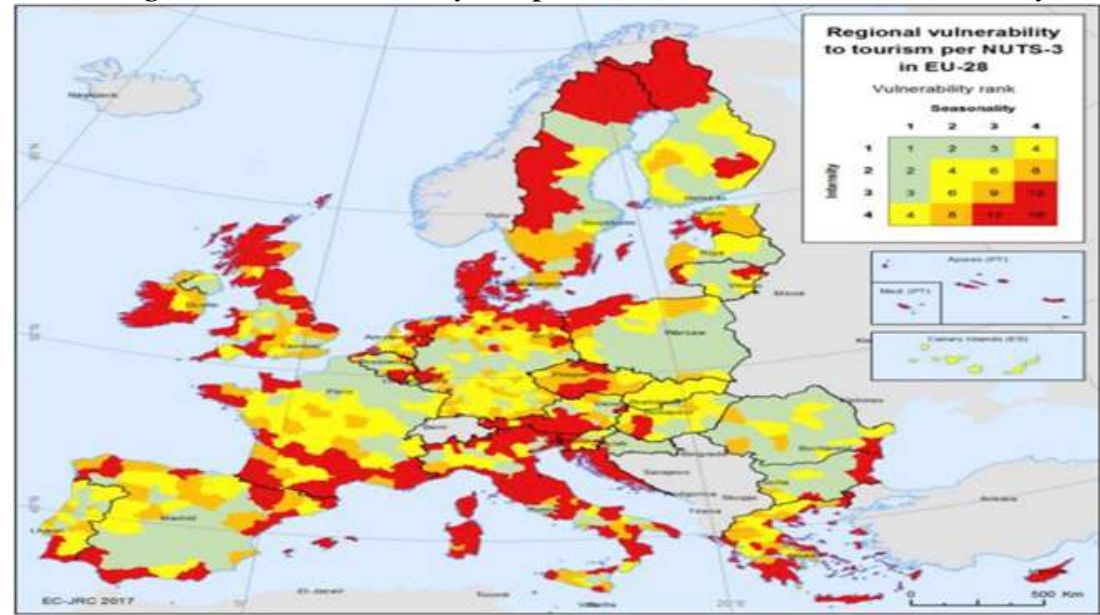

Source: Authors' caption from the European Commission, (2020), Tourism and transport in 2020 and beyond, (05 March 2021)

The main objective of this paper is to provide a synoptic analysis of the evolution of the tourism sector, in the first year of the pandemic, compared to a previous period (2018-2019), in the context of a growing global trend to reconfigure this economic sector. For this, the data available from Eurostat regarding the evolution of some indicators appreciated as significant and representative for the field were taken into account. The paper was structured in a classical manner: the introductory section, which includes a brief foray into the specialized literature, is completed with two distinct subsections related to the periods until the pandemic and during the pandemic, in which major trends specific to the field are analyzed. The

\footnotetext{
${ }^{3}$ According to JRC methodology the vulnerability index is peer-reviewed rank calculated taking into account two other representative indicators: tourism intensity and seasonality.
} 
concluding part of the paper concentrates the main conclusions and recommendations obtained following the analysis. The novelty of this research consists in trying to achieve an integrated approach to sectoral developments in tourism in some European countries, from a dual perspective, as previously described, and by including in the analysis the three states of the Western Balkans: Montenegro, R Serbia and North Macedonia.

\section{Approaches to tourism before and during COVID-19}

\section{a. Tourism before COVID-19. A short analysis during 2018-2019}

Tourism is an essential activity in the EU in ensuring economic growth and well-being for a significant part of the population, while aslo being an essential activity in many European areas and regions, as shown in Figure 2 and Table 1.

Table 1: Tourism trips, nights and expenditure of EU-27 residents by destination and month of departure, July-August 2018

\begin{tabular}{|c|c|c|c|c|c|}
\hline \multirow{2}{*}{ Indicator } & \multirow{2}{*}{$\begin{array}{c}\text { Entire } \\
\text { year } 2018\end{array}$} & \multirow{2}{*}{$\begin{array}{l}\text { July- } \\
\text { August }\end{array}$} & \multicolumn{3}{|c|}{$\begin{array}{l}\text { Share in the entire year } \\
2018\end{array}$} \\
\hline & & & $\begin{array}{c}\text { July- } \\
\text { August }\end{array}$ & July & August \\
\hline Total trips (thousand) & $\mid 1,133,696$ & 270,663 & $24 \%$ & $11 \%$ & $12 \%$ \\
\hline Domestic trips & 799,731 & 190,175 & $24 \%$ & $11 \%$ & $13 \%$ \\
\hline Outbound trips & 333,965 & 80,488 & $24 \%$ & $12 \%$ & $12 \%$ \\
\hline Other EU countries & 239,643 & 60,477 & $25 \%$ & $12 \%$ & $13 \%$ \\
\hline Rest of the world & 94,322 & 20,011 & $21 \%$ & $10 \%$ & $11 \%$ \\
\hline Total nights (thousand) & $5,882,100$ & $1,927,447$ & $33 \%$ & $17 \%$ & $16 \%$ \\
\hline Domestic trips & $3,306,662$ & $1,177,469$ & $36 \%$ & $18 \%$ & $18 \%$ \\
\hline Outbound trips & $2,575,439$ & 749,978 & $29 \%$ & $15 \%$ & $14 \%$ \\
\hline Other EU countries & $1,593,878$ & 511,260 & $32 \%$ & $16 \%$ & $16 \%$ \\
\hline Rest of the world & \begin{tabular}{|l|}
981,560 \\
\end{tabular} & 238,718 & $24 \%$ & $13 \%$ & $11 \%$ \\
\hline $\begin{array}{c}\text { Total expenditure } \\
\text { (mil.Euro) }\end{array}$ & 516,713 & 137,621 & $27 \%$ & $13 \%$ & $14 \%$ \\
\hline Domestic trips & 206,654 & 60,868 & $29 \%$ & $14 \%$ & $15 \%$ \\
\hline Outbound trips & 310,059 & 76,753 & $25 \%$ & $12 \%$ & $13 \%$ \\
\hline Other EU countries & 173,680 & 48,612 & $28 \%$ & $13 \%$ & $15 \%$ \\
\hline Rest of the world & 136,379 & 28,141 & $21 \%$ & $11 \%$ & $10 \%$ \\
\hline
\end{tabular}

Source: Authors based on Eurostat, (2020), Tourism in the EU - what a normal summer season looks like - before Covid-19, (05 March 2021) 
In order to highlight both the importance of tourism in the European economy and to make a significant comparison of the two time periods considered in this paper, Table 1 comprises data on tourism trips, nights and expenditure of EU - 27 residents by destination and month of departure, between July-August 2018. Also, to complete this analysis, nights spent in tourist accommodation establishments, July-August 2019 are presented in Table 2.

Table 2: Nights spent in tourist accommodation establishments, JulyAugust 2019 (thousands)

\begin{tabular}{|c|c|c|}
\hline \multirow{2}{*}{} & \multicolumn{2}{|c|}{ Number of nights spent } \\
\cline { 2 - 3 } & Entire year 2019 & July-August \\
\hline EU-27 & $2,849,852$ & 914,878 \\
\hline Bulgaria & 27,155 & 12,363 \\
\hline Czech Rep. & 57,025 & 16,019 \\
\hline Estonia & 6,967 & 1,886 \\
\hline Greece & 119,515 & 50,778 \\
\hline Spain & 469,462 & 135,241 \\
\hline France & 446,467 & 165,804 \\
\hline Croatia & 91,178 & 53,245 \\
\hline Italy & 434,062 & 157,613 \\
\hline Cyprus & 18,056 & 5,263 \\
\hline Latvia & 5,510 & 1,524 \\
\hline Luxembourg & 2,917 & 893 \\
\hline Hungary & 33,079 & 9,978 \\
\hline Poland & 93,343 & 26,654 \\
\hline Romania & 29,870 & 9,465 \\
\hline Slovenia & 15,764 & 5,463 \\
\hline Slovakia & 17,225 & 4,671 \\
\hline Montenegro & 4,605 & 1,985 \\
\hline North Macedonia & 2,295 & 690 \\
\hline Serbia & 10,051 & 2,443 \\
\hline Sourc &
\end{tabular}

Source: Authors based on Eurostat, (2020), Tourism in the EU - what a normal summer season looks like - before Covid-19, (05 March 2021)

As observed from the combined analysis of the data presented in Tables 1 and 2, tourism and the European tourism industry have registered a relatively decreasing trend at least in terms of the total nights indicator. In 2018 there were 5,882,100 thousand nights, which in 2019 decreased to $2,849,852$ thousand nights, i.e. just over half the value recorded in the previous year. A determining factor is represented by the concentration of tourist activities during July-August, demonstrating the seasonality of this 
activity and consumers' preferences for sun tourism. Figure 3 shows the evolution of Nights spent in tourist accommodation establishments, JulyAugust 2019 as share in the entire year 2019.

Figure 3: Nights spent in tourist accommodation establishments, JulyAugust 2019 as share in the entire year 2019

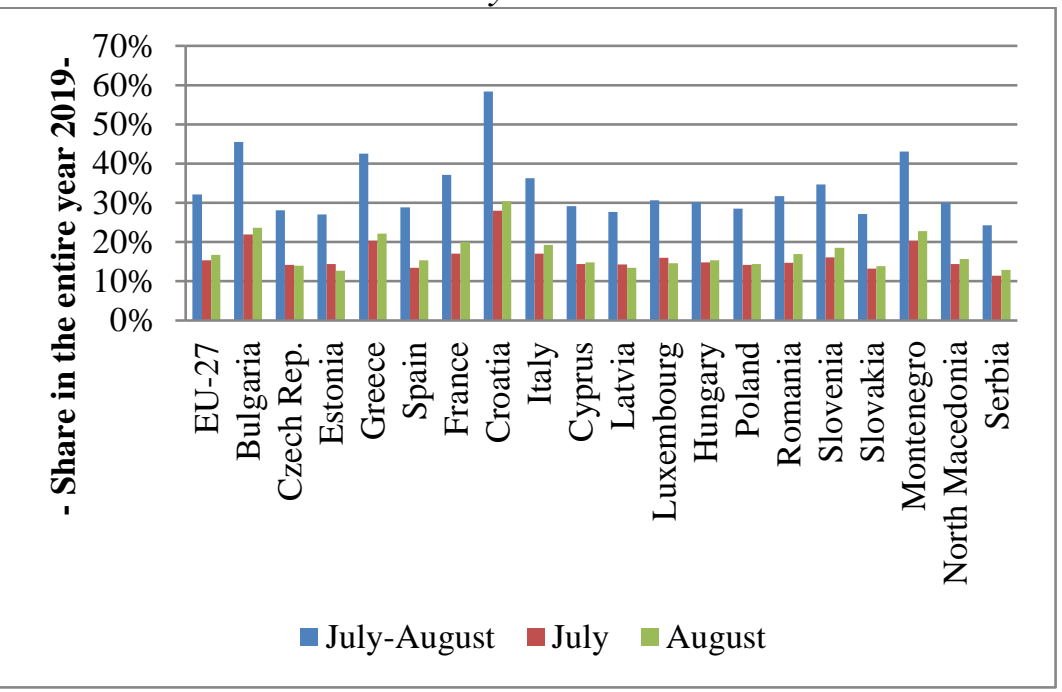

Source: Authors' computations based on Table 2

The capitalization of the economic potential of European tourism is strongly focused on achieving the exigencies of competitiveness, being an activity in a close correlation and determination with the ways of highlighting the cultural and natural heritage, the traditions and contemporary cultures of European states. The number of nights spent in tourist accommodation establishments is one of the relevant indicators in understanding the options of tourists to be attracted in a certain area, as well as of the convergence and diversity of the determined tourist offer.

The European tourism industry must adapt, to the point of compliance and understanding, to the demands imposed by the existence of increasing competition worldwide, starting from the reality that emerging or developing countries or regions propose and advance increasingly aggressive policies to attract tourists. In these conditions, the European tourism industry, faced with this superior dimension of competition by volume, must fundament a sustainable, resilient and quality tourist offer that will accentuate the existing comparative advantages. From this perspective we can easily argue that the evolution of the number of nights 
spent in tourist accommodation establishments is determined by the level of comparative advantages prevailing in each country, starting from the diversity of existing landscapes, the quality of reception structures and exceptional cultural richness and traditions. It must be taken into account that the tourist demand shows a high degree of fluctuation precisely due to economic, financial and political situations in a continuous change and global adaptation.

Under the impact of the need to increase competitiveness and the degree of attractiveness of tourist destinations, tourism and the tourism industry have required the development of an intelligent tourism ecosystem, as a comprehensive form of manifestation of specific tourist phenomena. It starts from the fundamental idea that nothing can work individually, without connection and interdependence, but all components of industry interact within an ecosystem to evolve.

Considering the indicators presented in Table 1, one can easily notice the interdependencies between the domestic tourism component (Domestic trips) and the external one (Outbound trips), as well as between the intraEuropean flows and those with the rest of the world. Thus, as argued by Bazargani \& Kiliç (2021), globally, the tourism industry is one of the most important economic sectors, which experiences the fastest growth, having an essential role in promoting local potential, in creating new jobs, even if some of a seasonal nature, triggering and potentiating the essential factors in promoting economic prosperity for many regions.

The outbreak of the COVID-19 health crisis has put tourism and the tourism industry in front of significant challenges, which at least the European economic space has not faced before. Although there are experiences from previous crises, often of an economic, financial or organizational nature, the need to adapt and reconsider the European tourism paradigm is much more pressing now. Tourism and the European tourism industry must develop appropriate forms to deal with the new restrictions imposed, starting with the transport of tourists and ending with the conditions of accommodation, social distance, volume and services offered. The turnover, the tourist circulation, the degree of occupation of the tourist capacities are just some of the elements that can be taken into account when trying to understand the new tourist paradigm. From this perspective, the second part of the paper is focused on the evolution of tourism and the European tourism industry during the COVID-19 crisis. 


\section{b. Tourism during COVID-19}

In order to understand the evolution of the European tourism paradigm in the beginning of the health crisis caused by COVID-19, in this section of the paper we chose to analyze only two indicators, which we consider relevant. The first of these is Index of turnover evolution in accommodation and food service activities, and the second, keeping the previous reference, is nights spent at tourist accommodation establishments. Figure 4 shows the evolution Index of turnover evolution in cases of accommodation and food service activities, during 2020, in the case of some European states. The turnover level is significant for the evolution of the tourism sector, highlighting the degree of sustainability of this activity, given that the significant volume of turnover is generated in the third and fourth quarters, related to sun tourism for most countries analyzed.

Figure 4: Index of turnover evolution in case of accommodation and food service activities, during 2020

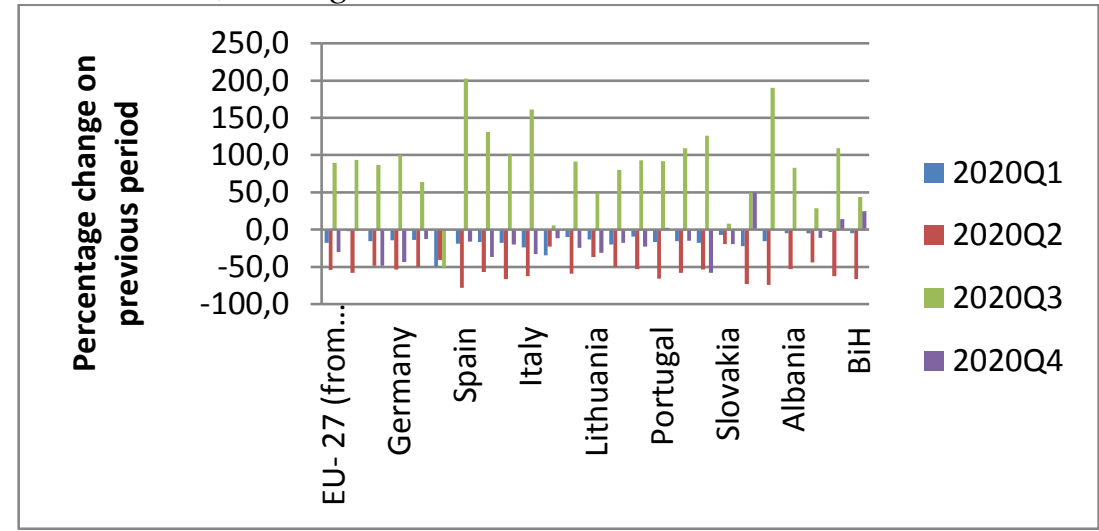

Source: Authors based on Eurostat, (2021). Tourism statistics - nights spent at tourist accommodation establishments, (05 March 2021)

As deriving from the data presented in the previous figure, tourism and the tourism industry have registered a significant sharp decline in revenues, being among the economic sectors that are most severely affected by the pandemic and whose return depends directly on the measures of limiting and combating it. Also deriving from Figure 4, the first and second quarters of 2020 represented for most of the analyzed states a reduction in turnover caused by the beginning of the health crisis generated by COVID-19. From this perspective, one can notice the significant level of influence that the limitation of the population circulation - including the touristic mobility had on the level of revenues in the tourism industry. Thus, at international 
level, World Tourism Organization - UNWTO (2020) estimates only for 2020 a volume decrease in tourism between $60 \%$ and $80 \%$, with financial losses between 910 billion USD to 1.2 trillion USD, starting from the reality that for the first quarter of the same year, international arrivals fell by $22 \%$. On the other hand, as noted by Tamás \& Árva (2020), the pandemic of COVID-19 has already caused serious, irreparable sectoral consequences, generating a 10-30\% decrease in global economic activities.

Returning to the second indicator considered, to exemplify this situation, Figure 5 presents annual estimates from the perspective of the number of nights spent at tourist accommodation establishments in the EU, for the period 2005-2020.

Figure 5: Annual estimates - Number of nights spent at tourist accommodation establishments, EU, 2005-2020 (index: 2005=100)

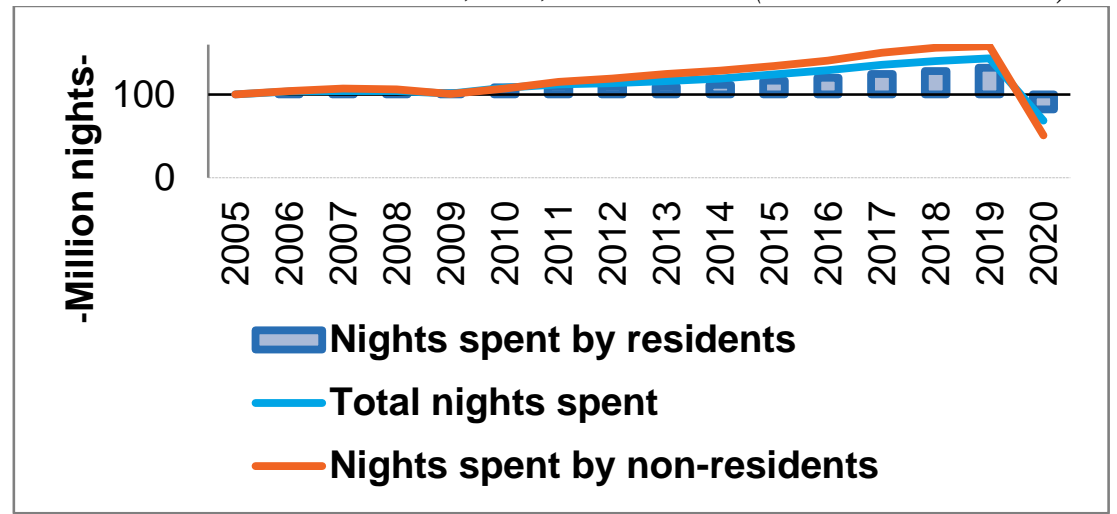

Source: Authors based on Eurostat, (2021), Tourism statistics - nights spent at tourist accommodation establishments, (05 March 2021)

As shown in Figure 5, for the period 2005-2019, the number of nights spent at tourist accommodation establishments is owned by non-resident tourists, starting with 2020, we are witnessing a change in the trend due to the application of traffic restrictions. Thus, the number of nights spent at tourist accommodation establishments decreases dramatically starting with 2020, as well as the structure of tourists, those who choose tourist destinations being mostly resident tourists. Therefore, epidemic and health crises, including that of COVID-19, can generate as claimed by Seraphin (2021) essential changes in the structure of tourism demand for certain destinations, starting from the reality that tourists are now put in the situation to decide consciously and informedly not to get exposed to such 
crises and to choose those destinations that they consider safe from a health point of view. Relevant in this respect are the data presented in Figure 6.

Figure 6: Evolution of the number of nights spent in EU tourist accommodation by origin of the guest (resident/non-resident), Jan-Dec 2019 and Jan-Dec 2020 (million nights)

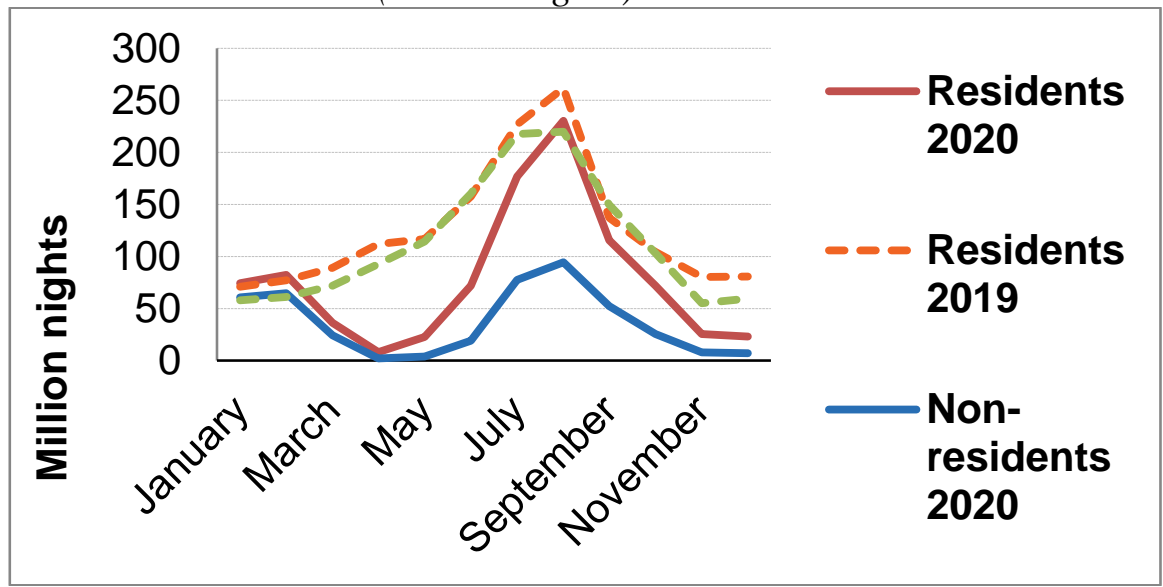

Source: Authors based on Eurostat, (2021), Tourism statistics - nights spent at tourist accommodation establishments, (05 March 2021)

As can be seen from the data presented in Figure 6, most of the analyzed states have applied travel restrictions, drastically limiting tourism and tourist circulation as part of measures to limit the spread of COVID-19. Thus, from the data presented by Eurostat (2021), at the level of 2020, the nights spent by non-residents (foreign guests) in the available tourist accommodation capacities decreased by $68 \%$, while the nights spent by residents (domestic tourists) also decreased by $38 \%$. If we consider the evolution of the number of nights spent in EU tourist accommodation by origin of the guest (resident/non-resident), for the period Jan-Dec 2019 (until the pandemic) and Jan-Dec 2020 (at one year of pandemic), the tendency of reverse internalization of the beneficiaries of tourist services is noticeable. If in 2019 the tourist demand in the form of number of nights spent in tourist accommodation was from non-residents, in 2020 the flow is reversed due to the application of travel restrictions. As highlighted in the report of Eurostat, the evolution of tourism and of the tourism industry at European level registered a positive trend, relatively significant, respectively with increases of 5\% in January and 6\% in February 2020, compared to the same months of 2019. However, the onset of the health crisis in March 2020 significantly disrupted the European tourism sector, as observed in Figure 7. Thus, according to Eurostat (2021), the evolution 
of the number of nights spent in EU tourist accommodation decreased dramatically, respectively by $62 \%$ compared to March 2019, precisely due to travel restrictions, closure of tourist units or blockages and limitations imposed in the management of the health crisis. From this perspective, as acknowledged by Rivera (2020), the analysis of the existing realities in the hospitality and tourism industry in the context generated by the COVID-19 pandemic is of paramount importance.

At the same time and for the same reasons, the health crisis can be associated with the reduction of the availability of the tourist offer. Therefore, the rapid outbreak and spread of COVID-19 has forced many tour operators to cease operations, and as evidenced by Fotiadis et al. (2021) many of the tourist destinations have been forced to stop operations or limit the volume of activity following the application of drastic traffic restrictions, the decrease of the volume of trips or the increase of the cancellation rate of the reservations or due to the limited logistics available.

Figure 7: Evolution of the number of nights spent in EU tourist accommodation, Jan-Dec 2019 and Jan-Dec 2020 (million nights)

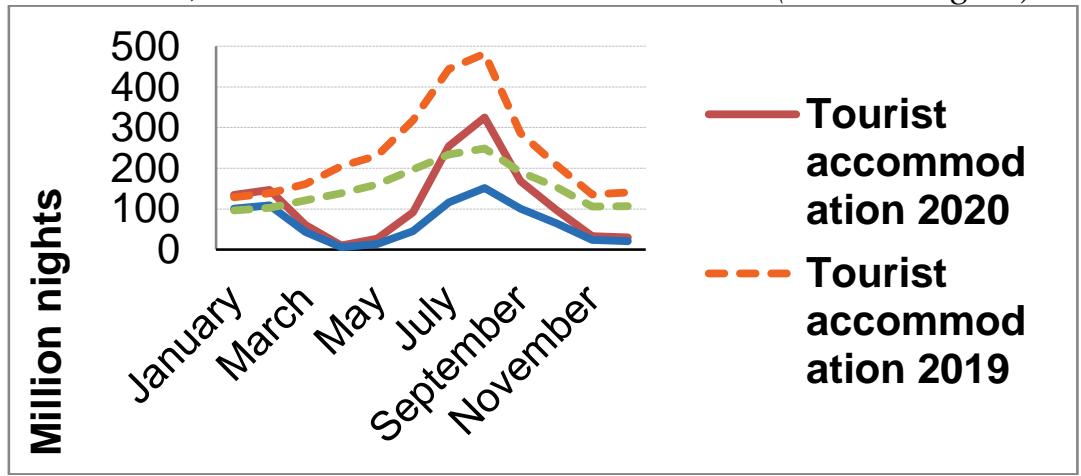

Source: Authors`own processing based on Eurostat, (2021), Tourism statistics - nights spent at tourist accommodation establishments, (05 March 2021)

In order to complete this overview, Figure 8 presents the change in the number of nights spent in tourist accommodation, October - December 2020 vs. the same period in $2019(\%)$. 
Figure 8: Change in number of nights spent in tourist accommodation, October - December 2020 vs. the same period in 2019 (\%)

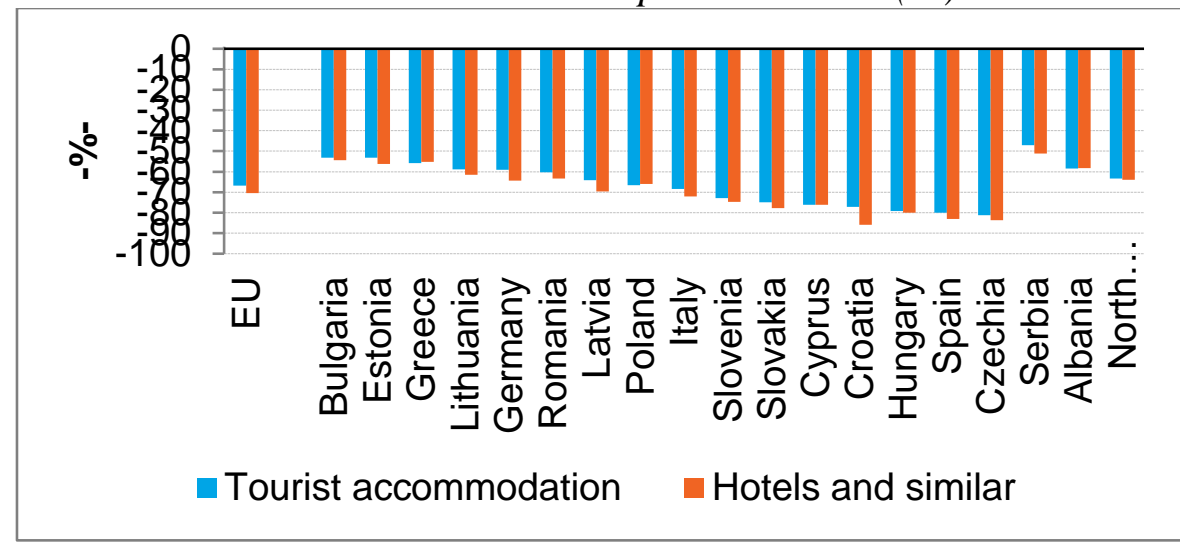

Source: Authors`own design based on Eurostat, (2021), Tourism statistics - nights spent at tourist accommodation establishments, (05 March 2021)

Figure 8 shows the significant change in the number of nights spent in tourist accommodation, October - December 2020 vs. the same period in 2019 , in the case of the analyzed states. Given that according to the European Commission (2020), tourism and the tourism industry represent at European level the fourth largest category of exports in the whole economy, the decrease of tourism activities produces a negative driving effect on the whole European economy and on directly connected sectors, such as air transport or the leisure sector. The collateral training benefits generated by tourism on other economic branches, represent in this context one of the essential factors that should be taken into consideration in rethinking the European tourism strategy towards being more connected to the economic realities. According to the same European document (European Commission, 2020), a euro related to the added value generated by tourism determines an additional added value of 56 cents from other sectors, which further sustains this indirect effect, of stimulating the development of other industries' potential.

\section{Conclusions}

Overcoming, limiting and counteracting the effects produced by the health crisis on tourism requires sustainable management of tourist destinations, starting with planning the efficient use of space and specific facilities, investments in infrastructure and services, health management and last but not least rethinking potential valorification strategies. The new orientation 
of tourism, both in scale, level and typology can consolidate the long-term development of this economic branch in terms of economic performance and sectoral position in the ensemble of national economic branches. The promotion of an articulated sectoral policy can determine a significant return of this field, considering the strong influence of tourism on stimulating economic growth and mobilizing resources in the economy, starting from its sustainable features that allow addressing the key challenges posed by the COVID-19 crisis in a much more reactive manner than other economic activities.

\section{Limitations and future researches}

The impact of the COVID-19 crisis on the tourism evolution is much deeper and with wider reverberations than can be analyzed at first sight. The present paper addresses only some strictly limited aspects, not taking into account a series of other specific indicators, precisely to highlight the impact of reducing the number of overnight stays, and furthermore, accommodation and the evolution of profit. This paper presents only a small, limited approach that could and should be complemented with the research on the influences on profit, employment and tariffs as well as on the transformation of mass tourism and the emergence of tourism forms well suited to health requirements.

\section{References}

1. Andrei, D.R., Gogonea, R.M., Zaharia, M., Andrei, J.V. (2014). Is Romanian Rural Tourism Sustainable? Revealing Particularities. Sustainability, Vol. 6, No. 12, 8876-8888.

2. Andrei, J.V., Drăgoi, M. C. (2020). A brief analysis of tourism economics in the EU - is there a massive economic potential change? TISC - Tourism International Scientific Conference, Vrnjačka Banja, 5(1), 5976.

3. Bazargani, R.H.Z., Kiliç, H. (2021). Tourism competitiveness and tourism sector performance: Empirical insights from new data. Journal of Hospitality and Tourism Management, Vol. 46, 73-82.

4. Chang, C.L., McAleer, M., Ramos, V. (2020). A Charter for Sustainable Tourism after COVID-19. Sustainability, Vol. 12, No. 9, 3671. 
5. Ciolac, R., Rujescu, C., Constantinescu, S., Adamov, T., Drăgoi, M. C., Lile, R. (2017). Management of a Tourist Village Establishment in Mountainous Area through Analysis of Costs and Incomes. Sustainability, Vol. 9, No. 6, 875 .

6. European Commission, (2007a), Agenda for a sustainable and competitive European tourism, https://eur-lex.europa.eu/legal-ontent/EN/ TXT/?uri=celex\%3A52007DC0621, (21 March 2021).

7. European Commission, (2007b), Promoting young people's full participation in education, employment and society, https://eurlex.europa.eu/LexUriServ/LexUriServ.do?uri=COM:2007:0498:FIN:EN: PDF, (05 March 2021).

8. European Commission, (2020), Tourism and transport in 2020 and beyond. https://eur-lex.europa.eu/legal-content/EN/TXT/PDF/?uri= CELEX:52020DC0550\&from=EN, (05 March 2021).

9. Eurostat, (2020), Tourism in the EU - what a normal summer season looks like - before Covid-19, https://ec.europa.eu/eurostat/statisticsexplained/index.php?title=Tourism_in_the_EU_-_what_a_normal_ summer_season_looks_like_-_before_Covid-19\#Europeans_spend_ more_than_500_million_overnights_in_the_EU, (05 March 2021).

10. Eurostat, (2021), Tourism statistics - nights spent at tourist accommodation establishments, https://ec.europa.eu/eurostat/statisticsexplained/index.php?title=Tourism_statistics_-_nights_spent_at_tourist_ accommodation_establishments\&stable=0\#Focus_on_fourth_quarter_of_ 2020, (05 March 2021).

11. Fotiadis, A., Polyzos, S., Huan, T.C.T. (2021). The good, the bad and the ugly on COVID-19 tourism recovery. Annals of Tourism Research, Vol. 87, 103117.

12. Higgins-Desbiolles, F. (2021). The "war over tourism": challenges to sustainable tourism in the tourism academy after COVID-19. Journal of Sustainable Tourism, Vol. 29, No. 4, 551-569.

13. Lapointe, D. (2020). Reconnecting tourism after COVID-19: the paradox of alterity in tourism areas. Tourism Geographies, Vol. 22, No. 3, 633-638. 
14. Lew, A. A., Cheer, J. M., Haywood, M., Brouder, P., Salazar, N. B. (2020). Visions of travel and tourism after the global COVID-19 transformation of 2020. Tourism Geographies, Vol. 22, No. 3, 455-466.

15. Nepal, S. K. (2020). Adventure travel and tourism after COVID-19business as usual or opportunity to reset? Tourism Geographies, Vol. 22, No. 3, 646-650.

16. Rifkin, J. (2019). The Green New Deal: Why the Fossil Fuel Civilization Will Collapse by 2028, and the Bold Economic Plan to Save Life on Earth, St. Martin's Press, New York.

17. Rivera, M. A. (2020). Hitting the reset button for hospitality research in times of crisis: Covid19 and beyond. International Journal of Hospitality Management, Vol. 87, 102528.

18. Seraphin, H. (2021). COVID-19: an opportunity to review existing grounded theories in event studies. Journal of Convention \& Event Tourism, Vol. 22, No.1, 3-35.

19. Strielkowski, W. (2020). International Tourism and COVID-19: Recovery Strategies for Tourism Organisations. Preprints, 2020030445. https://doi.org/10.20944/preprints202003.0445.v1.

20. Tamás, V., Árva, L. (2020). Toward Complex and Sustainable Tourism in Hungary. Polgári Szemle, Vol. 16, (Special Issue), 85-102.

21. Villacé-Molinero, T., Fernández-Muñoz, J.J., Orea-Giner, A., FuentesMoraleda, L. (2021). Understanding the new post-COVID-19 risk scenario: Outlooks and challenges for a new era of tourism. Tourism Management, Vol. 86, 104324.

22. World Tourism Organization - UNWTO, (2020), International tourist number could fall 60-80\% in 2020., https://www.unwto.org/news/covid19-international-tourist-numbers-could-fall-60-80-in-2020, (05 March 2021).

23. Zhang, H., Song, H., Wen, L., Liu, C. (2021). Forecasting tourism recovery amid COVID-19. Annals of Tourism Research, Vol. 87, 103149. 